\title{
More tests required on new chemicals
}

\author{
THE Environmental Protection Agency has for the first time \\ used its powers to block the introduction of new chemicals, \\ which have not been tested sufficiently for safety. \\ David Dickson reports
}

EVER since the Toxic Substances Control Act (TSCA) was passed by Congress in 1976 , it has remained the centre of fierce controversy. The chemical industry has claimed that many of its rules on new and existing chemicals impose an unduly harsh economic burden; environmentalist groups argue that the Environmental Protection Agency has been dragging its feet in enforcing the Act.

Now the Agency has decided to bare its teeth. Under a section of the Act requiring all companies to provide premanufacturing notices (PMNs) containing data on safety tests before a new chemical is introduced, the EPA last week announced that it was blocking the manufacture of six chemicals for which it felt that data submitted were inadequate.

The name of the company is being withheld at its request. However the EPA said that the chemicals are six phthalate esters, members of a group of so-called plasticisers which are added to polyvinyl chloride products to make them flexible, and that proposed production levels would involve 300 to 400 production workers, and up to 10,000 plastic goods workers.

The EPA's actions are based partly on the results of a study being carried out by the National Cancer Institute which seems to be proving that DEHP, a widely-used plasticiser with a similar chemical structure, can cause liver cancer in mice and rats.

According to the agency, the company proposing to manufacture the new phthalate esters had not been aware of the NCI studies. And in submitting the PMN, it provided no reports on safety studies, leading the EPA to assume that none had been carried out.

EPA Deputy Administrator Barbara Blum said last week that, before manufacture is allowed to proceed, the company must provide information about the potential carcinogenicity of the new chemicals.

The action is the strongest so far to have been taken by the Agency under the TSCA. This reflects feeling among officials that some chemical companies are being excessively reluctant to provide data.

In a recent letter to a Congressional Subcommittee, for example, Dr Stephen Jellinek, Assistant Administrator for Toxic Substances, wrote that the lack of adequate test information was contrary to congressional intent in passing the Act, and "contradicts industry's oft-expressed view of how it conducts its premanufacture activities",

Under the provisions of TSCA, companies must submit all existing test data about the safety of a new chemical, but are not required to carry out any additional tests unless the EPA determines that the production of the chemical could pose an "unreasonable risk" or would be in particularly large quantities. Environmental groups have criticised the flexibility of this arrangement. They argue that the EPA could have been more aggressive.

"The EPA says that the Act does not give them authority to promulgate rules for tests. But we feel that the Act does give it the power to gather any information they feel is necessary," says Dr Karim Ahmed of the Natural Resources Defense Council (NRDC).

The NRDC has already successfully sued the EPA over delays in implementing another section of the Act, which requires it to take action on a priority list of potentially dangerous chemicals drawn up by an interagency committee.

The Agency had argued that a 12-month time limit set by the Act required it merely to publish a progress report. However, three months ago a district judge in New York upheld the NRDC's contention that the actions themselves had to be carried out within this time. He said the 28 months which had elapsed since the priority list was published, and during which the EPA had taken no action against any of the listed chemicals, did not fulfil the congressional requirement.

NRDC members claim that the court victory strengthens their argument that the EPA could be moving more firmly to implement the provisions of the TSCA. In particular, it is arguing that the Agency has the power to set guidelines for the type of safety test data required to be submitted with PMNs.

This would bring the US more in line with actions recommended by the European Economic Commission that before starting production of a new chemical, a company would have to provide a certain amount of data on its potential environmental and health effects, in this case the amount of data depending on the proposed level of production.

The NRDC is proposing a 'tiered' scale of tests, with short term tests - for example for mutagenicity or chronic toxicity - required for all chemicals, and additional tests for those which are more likely to be dangerous.

This approach, however, is being resisted by the chemical industry. "You have to consider how each chemical is going to be used. To have a laundry list of tests is too simplistic', says Dr Geraldine Cox, Technical Director of the Chemical Manufacturers' Association, who says that the current arrangement allows companies to talk to the EPA on a "scientist to scientist" basis.

Last week's actions indicate that the agency intends to "prosecute vigorously" the PMN provisions, according to one official. Its apparent commitment to a more aggressive stance on chemical testing was illustrated two days after the phthalate esters announcement, when Ms Blum told several leading chemical manufacturers that new safety tests would have to be carried out on the herbicide 2,4-D.

Unlike 2,4,5-T, 2,4-D does not contain dioxin contaminants, and there is no direct evidence that it is a health hazard. However, because of the structural similarity between the two substances, the EPA is demanding that new studies be carried out to eliminate any suspicion that it might be dangerous.

\section{Record rise in federal R\&D backing}

FEDERAL support for university-based research and development increased by $\$ 610$ million to a total of $\$ 3,958$ million between 1977 and 1978, the largest net growth since records were started in the early $1960 \mathrm{~s}$ and the largest percentage growth since 1972, according to figures released by the National Science Foundation. The largest part of this increase came from the National Institutes of Health, whose support for university research increased by $\$ 262$ million. The 1978 figures represented an $8 \%$ real growth in funding over 1977.

The NSF statistics indicate that the majority of research support is concentrated in relatively few institutions. In 1963, when records were first compiled, $90 \%$ of federal R \& D support went to the top 100 research universities. In 1978 , the top 100 universities received $84 \%$ of all R \& D funds, compared to only $56 \%$ of total federal funds to universities.

Top recipient was Johns Hopkins University, whose \$196 million of federal support - largely the result of incorporating for the first time the Defense Department-sponsored Applied Physics Laboratory - put the university far ahead of the previous leader, the Massachusetts Institute of Technology. 